\title{
ASSESSMENT OF GROUNDWATER QUALITY FROM INDUSTRIAL AND RESIDENTIAL AREAS OF SANGO OTA, NIGERIA
}

\author{
O.A. Oguntade ${ }^{1 *}$, V.I. Ifesiokwu ${ }^{1}$ and O. S. Sule ${ }^{2}$ \\ ${ }^{1}$ Department of Crop Production, College of Agricultural Sciences, Olabisi Onabanjo University, P.M.B. \\ 0012, Ayetoro Campus, Ayetoro, Ogun State, Nigeria; \\ ${ }^{2}$ Department of Forestry, Wildlife, and Fisheries, College of Agricultural Sciences, Olabisi Onabanjo \\ University, P.M.B. 0012, Ayetoro Campus, Ayetoro, Ogun State, Nigeria \\ *Corresponding author: deletade@yahoo.com; dele.oguntade@oouagoiwoye.edu.ng, +2348035232706 \\ Received 11 November 2020; accepted 18 December 2020, published online 30 March 2021
}

\begin{abstract}
High concentration of contaminants in drinking water can affect human health. This study assessed quality of groundwater at industrial and residential areas of Sango Ota, Ogun State. Water samples were collected in triplicates from 8 wells at industrial and residential areas and analyzed for its physicochemical properties. The $\mathrm{pH}$, electrical conductivity, total dissolved solid (TDS), nitrate, sulphate, total suspended solid (TSS), total hardness (TH), iron, zinc, copper, lead, nickel, chromium and cadmium concentrations in the water samples were determined following American Public Health Association (APHA) procedure. Results showed that $\mathrm{pH}$ of $50 \%$ of the wells were lower than minimum limit of 6.5 recommended by WHO. Sulphate, TH and iron in the water were significantly $(p \leq 0.05)$ higher at residential area than industrial area. Electrical conductivity exhibited significant $(p \leq 0.01)$ correlation with TDS $\left(\mathrm{r}=0.701^{* *}\right)$ and $\mathrm{NO}_{3}{ }^{2-}\left(\mathrm{r}=0.922^{* *}\right)$ at residential area. At the industrial area however, concentration of salts in water samples was highly associated with $\mathrm{SO}_{4}{ }^{2-}\left(\mathrm{r}=0.864^{* *}\right)$ and $\mathrm{Cd}(\mathrm{r}=$ $0.587^{* * *}$ ). Across locations of groundwater, iron and lead were above allowable WHO limits in drinking water. Cadmium was also above drinking limit at location T4 of the residential area. Consumers of groundwater in the study area are prone to health related challenges of heavy metal toxicity.
\end{abstract}

Keywords: Groundwater, heavy metals, industrial, physicochemical, residential

\section{INTRODUCTION}

Water is one of the most abundant natural resources essential for survival of all living organisms. A major source of natural water which is available for drinking, bathing, washing, aquaculture, agricultural and industrial uses is the groundwater. The quality of groundwater as an important source of freshwater reserves on which urban and rural population depend is been threatened due to population growth and anthropogenic activities $[1,2]$. The high rate and improper management of waste generated in towns and cities due to urbanization and industrialization have also contributed to groundwater contamination [3, 4, 5]. Besides, factors such as the topography of the land, geology, weathering, mineral composition of the aquifer, water bed-rock interaction and anthropogenic activities can influence groundwater quality $[6,7,8]$.

Contamination of groundwater therefore, is an environmental issue of health concern that requires attention particularly in areas without potable water. Consumption of water contaminated by excess chemicals from natural and or anthropogenic sources can lead to health related problems [2]. Among the diversity of contaminants of health concerns that can migrate down the soil profile and contaminate aquifers are the heavy metals due to their toxicity even at low concentrations $[9,10]$. Studies have also shown that contamination of shallow groundwater by nitrate, sulphate, fluoride, total dissolved solid, and heavy metals makes groundwater unsuitable for drinking and for other purposes $[2,11,12,13]$. In addition, dust that settles on air from industrial operations as well as wastewater that leaches through the soils are among the contributors to surface and groundwater quality contamination $[14,15]$.

Sango-Ota is a major industrial area of Ogun State due to its nearness to Lagos State which is the most populous state in Nigeria. The population explosion of Lagos State which has extended to Owode area of Sango Ota has led to increase in water demand in the area. In 
addition, the topography of Owode area of Sango Ota is in the lowland making the area vulnerable to pollution from runoff and contamination of groundwater by domestic and industrial waste. Therefore, to determine the safety of groundwater used for drinking and domestic purposes in the study area where people rely on their private wells for water use, an assessment of quality of such water is necessary. The objectives of this study therefore, was to (1) determine the concentrations of water quality indicators including; $\mathrm{pH}$, electrical conductivity (EC), total dissolved solid (TDS), nitrate, sulphate, total suspended solid (TSS), total hardness $(\mathrm{TH})$ and (2) determine the levels of selected heavy metals such as iron $(\mathrm{Fe})$, zinc $(\mathrm{Zn})$, copper $(\mathrm{Cu})$, lead $(\mathrm{Pb})$, nickel $(\mathrm{Ni})$, chromium $(\mathrm{Cr})$ and cadmium $(\mathrm{Cd})$ in the hand dug wells around industrial and residential areas in Sango Ota.

\section{MATERIALS AND METHODS Water Sample Collection}

Two liters of groundwater samples were collected in plastic containers previously washed with liquid detergent and thoroughly rinse with de-ionized water. The water samples were collected in triplicates from eight different hand dug wells. Four of the water samples were collected from wells in the proximity of industrial area at Sango Ota while the other four were from residential area at Owode town a suburb of Sango Ota. Owode town is located at Sango Ota along Lagos-Abeokuta Express road in Ogun State. The samples were collected in the month of June, 2016. The locations of the hand dug wells sampling points coordinates as indicated by Global Positioning System (GPS) was presented in Figure 1.

\section{Water Sample Preparation and Analyses}

Water samples collected in clean plastic bottles ( 1 L capacity) kept in cooler contain ice block were transported to laboratory for analyses. The samples were kept in the refrigerator at $4{ }^{\circ} \mathrm{C}$ in the laboratory for analyses within five (05) days. Physicochemical properties of the water samples were determined according to standard methods. The $\mathrm{pH}$ was measured with $\mathrm{pH}$ glass electrode $\mathrm{pH}$ meter. Electrical Conductivity (EC) was measured with conductivity meter. Sulphate
$\left(\mathrm{SO}_{4}{ }^{2-}\right)$ was determined by turbidimeteric method at an absorbance of $425 \mathrm{~nm}$ on a UVVisible spectrophotometer (Model: UVmini1240/UVmini-1240V, Shimadzu Corporation Analytical \& Measuring Instruments Division, Kyoto, Japan). Nitrate $\left(\mathrm{NO}_{3}^{-}\right)$was measured using the phenoldisulphonic method by reading the absorbance at $410 \mathrm{~nm}$. Total suspended solid (TSS) was determine by gravimetric analysis. Total hardness (TH) was determined using volumetric method. For the heavy metals, water samples were filtered through $125 \mathrm{~mm}$ Whatman filter paper (Sigma-Aldrich, Taufkirchen, Germany). Thereafter, concentrations of $\mathrm{Fe}, \mathrm{Zn}$, $\mathrm{Cu}, \mathrm{Pb}, \mathrm{Ni}, \mathrm{Cr}, \mathrm{Cd}$ were determined on Atomic Absorption Spectrophotometer -AAS, (Buck Scientific 210 VGP, Buck Scientific, Inc., East Norwalk, CT, USA). All analytical procedures were carried out as described by [16].

\section{Statistical Analysis}

Data generated from the samples were subjected to SPSS version 20.0 for statistical analysis. The physicochemical parameters were also correlated with the heavy metals using Pearson's correlation coefficient. Turkey HSD test was used to separate significant means at probability value of 0.05 .

\section{RESULTS AND DISCUSSION Physicochemical Property of Water Sample}

The physicochemical property of the groundwater (Table 2) shows that $\mathrm{pH}$ of the water samples from industrial areas was highest at location $\mathrm{T} 1$ and was very slightly acidic. On the other hand, the highest $\mathrm{pH}$ at the residential areas was at location $\mathrm{T} 2$ which was very slightly alkaline. Across the four locations in both areas, two locations (T2 and T3 at industrial) as well as ( $\mathrm{T} 1$ and $\mathrm{T} 3$ at residential) the $\mathrm{pH}$ value was less than the lower limit of 6.5 recommended by [17]. This shows that people from $50 \%$ of the study area had been drinking well water with $\mathrm{pH}$ values less than minimum required. The $\mathrm{pH}$ values reported in this study was similar to what [10] reported for groundwater samples of Lagos and Ogun State. The EC and TSS were very low at both the industrial and residential areas. The TDS was in many folds higher at the various locations in the industrial areas compared to residential areas but was far lower than WHO limits. [18] had also reported lower TDS value 
than WHO limit in groundwater at Owo, southwest Nigeria. The low levels of EC, TSS and TDS indicated that the groundwater was suitable for drinking. Except at location T4, the $\mathrm{NO}_{3}{ }^{-}$content of the water samples was higher at the industrial areas compared to residential areas. The $\mathrm{NO}_{3}{ }^{-}$concentration of the wells does not pose any health threat because it was lower than $50 \mathrm{mg} / \mathrm{L}$ allowable limit in drinking water [17]. Previous study by [19] also reported low concentration of nitrate-nitrogen in groundwater of southwest Nigeria. Across locations, sulphate $\left(\mathrm{SO}_{4}{ }^{2-}\right)$ concentration in the groundwater was two to three folds higher in the residential area compared with industrial area except at location T2. Total hardness (TH) across the four locations range from 20.33 to $70.00 \mathrm{mg} / \mathrm{L}$ at the industrial area and it range from 26.67 to 90.33 $\mathrm{mg} / \mathrm{L}$ at the residential area. The $\mathrm{TH}$ followed a trend similar to that of $\mathrm{SO}_{4}{ }^{2-}$ with higher concentration in the groundwater at residential than industrial area (Figure 1 a). Higher concentrations of $\mathrm{SO}_{4}{ }^{2-}$ and $\mathrm{TH}$ at the residential area compared to industrial area could be due to higher domestic activities that made wells to be left opened more often and consequently being easily contaminated.

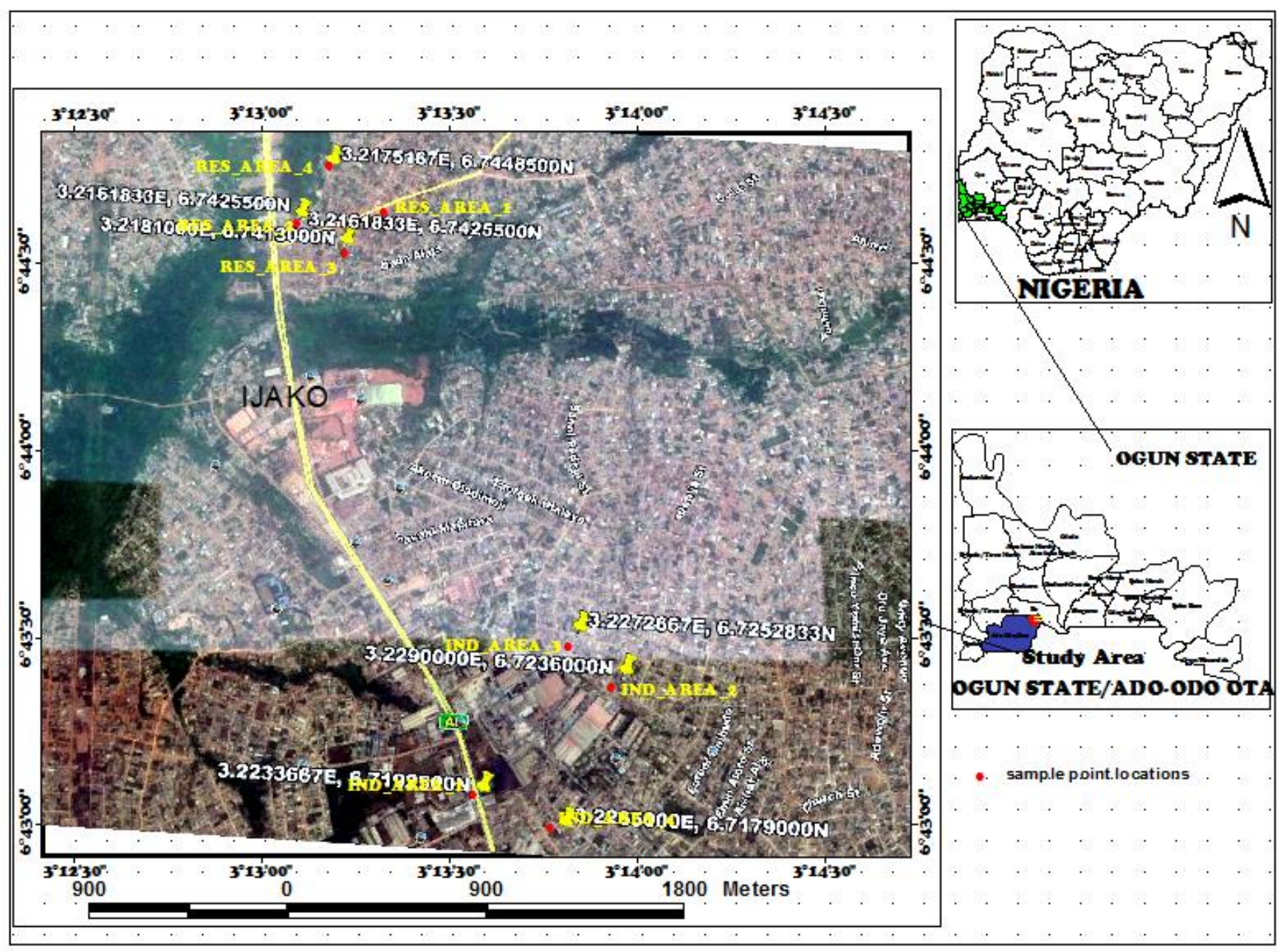

Figure 1: map of the study area showing sampling point locations 
Table 2: Physicochemical Properties of Groundwater Samples at different locations of Industrial and Residential Areas of Sango Ota (mean \pm SD)

\begin{tabular}{ccccccc}
\hline Parameter & Area & \multicolumn{4}{c}{ Location } & \multicolumn{2}{c}{ WHO } \\
& & $\mathrm{T} 1$ & $\mathrm{~T} 2$ & $\mathrm{~T} 3$ & $\mathrm{~T} 4$ & limits [17] \\
\hline $\mathrm{pH}$ & Industrial & $6.77 \pm 0.07^{\mathrm{a}}$ & $6.37 \pm 0.06^{\mathrm{c}}$ & $6.23 \pm 0.09^{\mathrm{d}}$ & $6.50 \pm 0.00^{\mathrm{b}}$ & $6.5-8.5$ \\
& Residential & $6.43 \pm 0.06^{\mathrm{c}}$ & $7.23 \pm 0.08^{\mathrm{a}}$ & $6.37 \pm 0.06^{\mathrm{c}}$ & $6.57 \pm 0.09^{\mathrm{b}}$ & \\
$\mathrm{EC}(\mu \mathrm{S} / \mathrm{cm})$ & Industrial & $1.13 \pm 0.06^{\mathrm{a}}$ & $1.03 \pm 0.06^{\mathrm{b}}$ & $0.57 \pm 0.04^{\mathrm{c}}$ & $1.20 \pm 0.00^{\mathrm{a}}$ & 250 \\
& Residential & $1.47 \pm 0.06^{\mathrm{b}}$ & $0.47 \pm 0.05^{\mathrm{d}}$ & $0.83 \pm 0.06 \mathrm{c}$ & $1.73 \pm 0.07^{\mathrm{a}}$ & \\
$\mathrm{TSS}(\mathrm{mg} / \mathrm{L})$ & Industrial & $0.022 \pm 0.00^{\mathrm{b}}$ & $0.018 \pm 0.02^{\mathrm{c}}$ & $0.034 \pm 0.01^{\mathrm{a}}$ & $0.022 \pm 0.00^{\mathrm{b}}$ & $\mathrm{N} / \mathrm{A}$ \\
& Residential & $0.052 \pm 0.04^{\mathrm{a}}$ & $0.030 \pm 0.01^{\mathrm{c}}$ & $0.031 \pm 0.03^{\mathrm{c}}$ & $0.032 \pm 0.00^{\mathrm{b}}$ & \\
$\mathrm{TDS}(\mathrm{mg} / \mathrm{L})$ & Industrial & $0.179 \pm 0.00^{\mathrm{b}}$ & $0.882 \pm 0.03^{\mathrm{a}}$ & $0.168 \pm 0.01^{\mathrm{c}}$ & $0.078 \pm 0.02^{\mathrm{d}}$ & 250 \\
& Residential & $0.035 \pm 0.04^{\mathrm{c}}$ & $0.070 \pm 0.00^{\mathrm{a}}$ & $0.071 \pm 0.02^{\mathrm{a}}$ & $0.068 \pm 0.01^{\mathrm{b}}$ & \\
$\mathrm{NO}_{3}{ }^{-}(\mathrm{mg} / \mathrm{L})$ & Industrial & $0.77 \pm 0.03^{\mathrm{a}}$ & $0.55 \pm 0.01^{\mathrm{b}}$ & $0.78 \pm 0.04^{\mathrm{a}}$ & $0.55 \pm 0.02^{\mathrm{b}}$ & 50 \\
& Residential & $0.40 \pm 0.01^{\mathrm{b}}$ & $0.41 \pm 0.00^{\mathrm{b}}$ & $0.41 \pm 0.02^{\mathrm{b}}$ & $0.59 \pm 0.01^{\mathrm{a}}$ & \\
$\mathrm{SO}_{4}{ }^{2-}(\mathrm{mg} / \mathrm{L})$ & Industrial & $0.82 \pm 0.03^{\mathrm{c}}$ & $1.29 \pm 0.01^{\mathrm{b}}$ & $0.33 \pm 0.04^{\mathrm{d}}$ & $1.45 \pm 0.01^{\mathrm{a}}$ & 250 \\
& Residential & $3.71 \pm 0.02^{\mathrm{b}}$ & $0.16 \pm 0.01^{\mathrm{d}}$ & $2.13 \pm 0.06^{\mathrm{c}}$ & $4.36 \pm 0.04^{\mathrm{a}}$ & \\
$\mathrm{TH}(\mathrm{mg} / \mathrm{L})$ & Industrial & $70.00 \pm 0.00^{\mathrm{a}}$ & $50.67 \pm 0.59^{\mathrm{b}}$ & $24.33 \pm 0.58^{\mathrm{c}}$ & $20.33 \pm 0.60^{\mathrm{d}}$ & 500 \\
& Residential & $90.33 \pm 0.57^{\mathrm{a}}$ & $28.00 \pm 0.00^{\mathrm{c}}$ & $40.33 \pm 0.58^{\mathrm{b}}$ & $26.67 \pm 0.56^{\mathrm{d}}$ & \\
\hline
\end{tabular}

$N / A=$ Not available; means in the same row with different superscript letters are significantly different ( $p \leq 0.05)$ according to Turkey HSD test.

\section{Heavy Metals in the Groundwater}

The concentration of heavy metals in the groundwater samples are shown in Table 3. Zinc concentration in the sampled wells was quite low across locations. Concentration of $\mathrm{Fe}$ range from $0.5 \mathrm{mg} / \mathrm{L}$ in location $\mathrm{T} 2$ to $1.07 \mathrm{mg} / \mathrm{L}$ in location $\mathrm{T} 3$ at the industrial area while it range from $0.78 \mathrm{mg} / \mathrm{L}$ in location $\mathrm{T} 3$ to $1.80 \mathrm{mg} / \mathrm{L}$ in location $\mathrm{T} 1$ at the residential area (Table 3 ). At both industrial and residential areas, concentration of Fe was two to six folds higher in the groundwater samples than $0.3 \mathrm{mg} / \mathrm{L}$ [20] limit for drinking water. Across locations, concentration of Fe was significantly $(p \leq 0.05)$ higher at the residential than industrial area (Figure $1 \mathrm{~b}$ ). The high concentration of $\mathrm{Fe}$ at residential area could be due to anthropogenic activities around the wells. When high concentration of $\mathrm{Fe}$ in drinking water enters into human body, the free irons penetrate into cells of the liver, heart and brain causing severe damage of the organs [21, 22]. Cadmium was detected only in water sample collected at location T4 of the residential area. Concentration of $\mathrm{Cd}$ at location T4 was however, higher than WHO permissible limit of $0.003 \mathrm{mg} / \mathrm{L}$. Previous study by [10] had also reported that $18 \%$ and $5 \%$ of groundwater from Lagos and Ogun sedimentary origin, respectively had $\mathrm{Cd}$ concentration higher than WHO limit. High bioavailability of $\mathrm{Cd}$ owing to being highly water soluble compared to other toxic metals made it accumulate and intoxicate body organs like kidney, lungs, bones [22, 23, 24].

At the industrial area, concentration of $\mathrm{Pb}$ was highest in location T2 while the lowest was recorded in location T1. Similarly at the residential area, well in location $\mathrm{T} 2$ had the highest $\mathrm{Pb}$ while location $\mathrm{T} 4$ had the lowest $\mathrm{Pb}$ concentration. This study revealed that $50 \%$ of the groundwater at both the industrial and 
residential areas had higher concentration of $\mathrm{Pb}$. This showed that half of the groundwater from either of the area was polluted by $\mathrm{Pb}$. Meanwhile, it was discovered that higher concentration of $\mathrm{Pb}$ was found in groundwater at the residential than industrial area (Figure $1 \mathrm{~b}$ ). In both areas, the concentration of $\mathrm{Pb}$ in the groundwater was between two to twenty three folds higher than $0.01 \mathrm{mg} / \mathrm{L}$ WHO limit for drinking water. This corroborates the findings of [22] that lead poisoning can occur through drinking water. High concentration of $\mathrm{Pb}$ in drinking water can cause kidney dysfunction and permanent brain damage among other chronic exposure [25].

Concentration of $\mathrm{Cu}$ in the groundwater was lowest $(0.05 \mathrm{mg} / \mathrm{L})$ in location $\mathrm{T} 1$ and highest $(0.15 \mathrm{mg} / \mathrm{L})$ in $\mathrm{T} 4$ at the industrial area. Conversely, at the residential area, the lowest $(0.03 \mathrm{mg} / \mathrm{L}) \mathrm{Cu}$ was in location $\mathrm{T} 4$ while the highest $(0.09 \mathrm{mg} / \mathrm{L})$ was in location $\mathrm{T} 2$. The wells at the industrial area were found to be more polluted with $\mathrm{Cu}$ than those at the residential area (Figure $1 \mathrm{~b}$ ).

At the industrial area, $\mathrm{Cr}$ was not detected in groundwater in location $\mathrm{T} 1$ and was highest $(0.03 \mathrm{mg} / \mathrm{L})$ in location $\mathrm{T} 3$. In contrary, it was only in location $\mathrm{T} 3$ that $\mathrm{Cr}$ was detected at the residential area. The concentration of $\mathrm{Cr}$ in the wells does not pose any threat to peoples' health since it was lower than $0.05 \mathrm{mg} / \mathrm{L}$ limit recommended by [17]. Across the locations, concentration of $\mathrm{Ni}$ in the groundwater was below detection limit.

\section{Correlation Analysis}

Table 4 shows the Spearman's correlation matrix of the groundwater quality parameters. The $\mathrm{pH}$ of the groundwater was positively correlated with $\mathrm{Pb}\left(\mathrm{r}=0.416^{*}\right)$ and negatively correlated with $\mathrm{Cr}\left(\mathrm{r}=-0.668^{* *}\right)$ at the industrial area. The correlation of $\mathrm{pH}$ with TSS $(\mathrm{r}=$ $\left.0.578^{* *}\right)$, TH $\left(\mathrm{r}=0.732^{* *}\right), \mathrm{Fe}\left(\mathrm{r}=0.549^{* *}\right)$ and $\mathrm{Cd}\left(\mathrm{r}=0.927^{* *}\right)$ was however, strong at the residential area. This indicated that the $\mathrm{pH}$ strongly influence these parameters. 

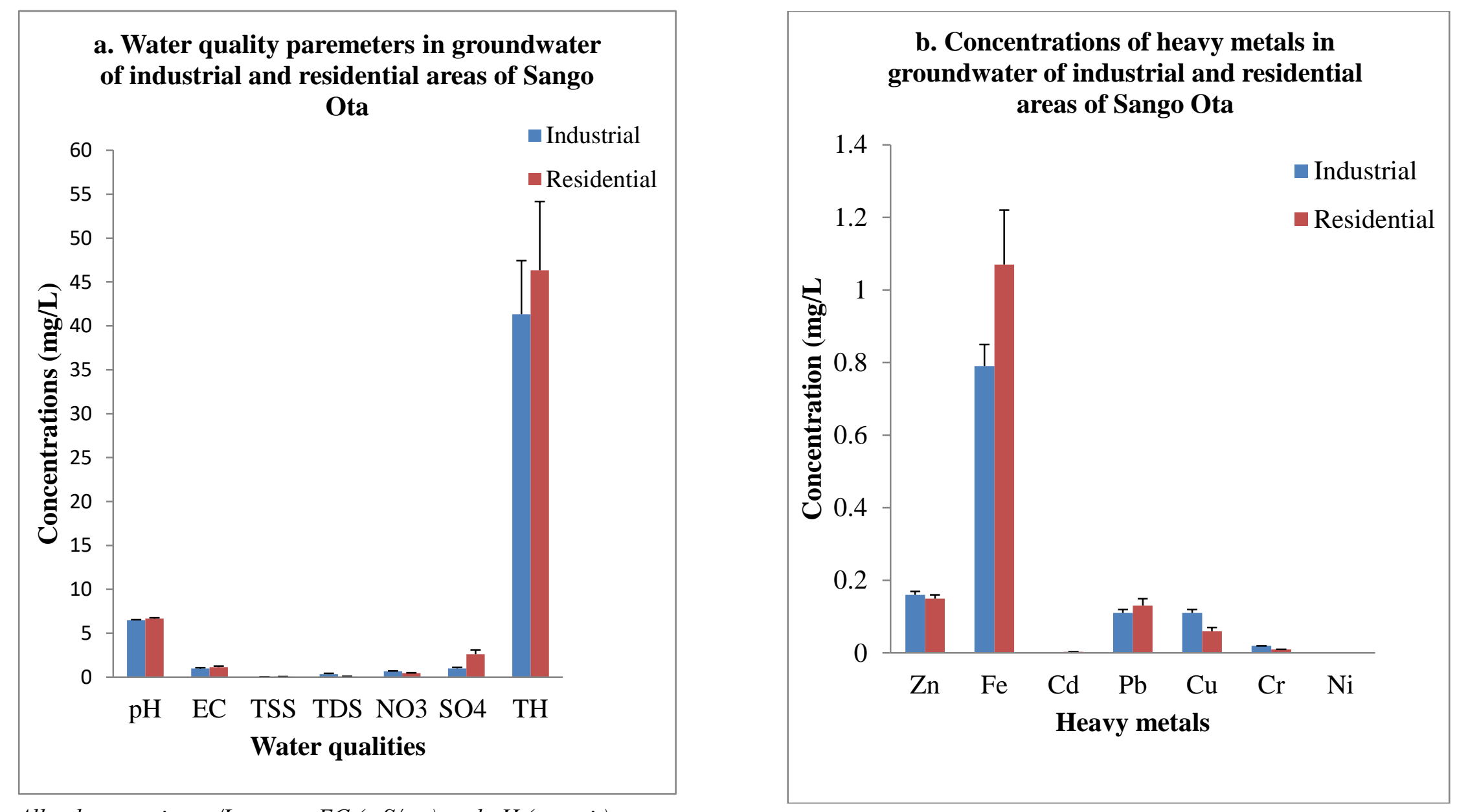

All values are in $\mathrm{mg} / \mathrm{L}$ except $E C(\mu \mathrm{S} / \mathrm{cm})$ and $p H$ (no unit)

Figure 1: Qualities and Heavy Metal Concentrations of Groundwater at Industrial and Residential Areas of Sango Ota 
Table 3: Concentrations of Heavy Metals in Groundwater Samples at different locations of Industrial and Residential Areas of Sango Ota (mean \pm SD)

\begin{tabular}{|c|c|c|c|c|c|c|}
\hline \multirow{2}{*}{$\begin{array}{l}\text { Parameters } \\
\mathrm{mg} / \mathrm{L}\end{array}$} & \multirow[t]{2}{*}{ Area } & \multicolumn{4}{|c|}{ Location } & \multirow{2}{*}{$\begin{array}{c}\text { WHO } \\
\text { Limits [17] }\end{array}$} \\
\hline & & T1 & $\mathrm{T} 2$ & T3 & $\mathrm{T} 4$ & \\
\hline \multirow[t]{2}{*}{$\mathrm{Zn}$} & Industrial & $0.13 \pm 0.02^{b}$ & $0.14 \pm 0.01^{b}$ & $0.19 \pm 0.04^{\mathrm{a}}$ & $0.18 \pm 0.03^{\mathrm{a}}$ & \multirow[t]{2}{*}{3.0} \\
\hline & Residential & $0.17 \pm 0.01^{\mathrm{a}}$ & $0.15 \pm 0.03^{b}$ & $0.15 \pm 0.02^{b}$ & $0.13 \pm 0.01^{\mathrm{c}}$ & \\
\hline \multirow[t]{2}{*}{$\mathrm{Fe}$} & Industrial & $0.80 \pm 0.02^{\mathrm{c}}$ & $0.50 \pm 0.01^{\mathrm{d}}$ & $1.07 \pm 0.04^{\mathrm{a}}$ & $0.82 \pm 0.02^{\mathrm{b}}$ & \multirow[t]{2}{*}{$0.3^{\dagger}$} \\
\hline & Residential & $1.80 \pm 0.03^{\mathrm{a}}$ & $0.81 \pm 0.01^{\mathrm{b}}$ & $0.78 \pm 0.57^{\mathrm{b}}$ & $0.90 \pm 0.00^{\mathrm{b}}$ & \\
\hline $\mathrm{Cd}$ & $\begin{array}{l}\text { Industrial } \\
\text { Residential }\end{array}$ & $\begin{array}{l}\text { BDL } \\
\text { BDL }\end{array}$ & $\begin{array}{l}\text { BDL } \\
\text { BDL }\end{array}$ & $\begin{array}{l}\text { BDL } \\
\text { BDL }\end{array}$ & $\begin{array}{l}\mathrm{BDL} \\
0.01 \pm 0.01^{\mathrm{a}}\end{array}$ & 0.003 \\
\hline \multirow[t]{2}{*}{$\mathrm{Pb}$} & Industrial & $0.06 \pm 0.02^{c}$ & $0.15 \pm 0.01^{\mathrm{a}}$ & $0.12 \pm 0.03^{b}$ & $0.10 \pm 0.02^{\mathrm{b}}$ & \multirow[t]{2}{*}{0.01} \\
\hline & Residential & $0.15 \pm 0.00^{b}$ & $0.23 \pm 0.02^{\mathrm{a}}$ & $0.09 \pm 0.04^{\mathrm{c}}$ & $0.02 \pm 0.01^{\mathrm{d}}$ & \\
\hline \multirow[t]{2}{*}{$\mathrm{Cu}$} & Industrial & $0.05 \pm 0.02^{c}$ & $0.10 \pm 0.04^{b}$ & $0.14 \pm 0.03^{\mathrm{a}}$ & $0.15 \pm 0.01^{\mathrm{a}}$ & \multirow[t]{2}{*}{2.0} \\
\hline & Residential & $0.06 \pm 0.03^{b}$ & $0.09 \pm 0.00^{\mathrm{a}}$ & $0.04 \pm 0.01^{\mathrm{c}}$ & $0.03 \pm 0.04^{\mathrm{d}}$ & \\
\hline \multirow[t]{2}{*}{$\mathrm{Cr}$} & Industrial & $\mathrm{BDL}$ & $0.02 \pm 0.03^{b}$ & $0.03 \pm 0.01^{\mathrm{a}}$ & $0.01 \pm 0.04^{\mathrm{c}}$ & \multirow[t]{2}{*}{0.05} \\
\hline & Residential & $\mathrm{BDL}$ & BDL & $0.02 \pm 0.00$ & BDL & \\
\hline \multirow[t]{2}{*}{$\mathrm{Ni}$} & Industrial & BDL & BDL & BDL & BDL & \multirow[t]{2}{*}{0.02} \\
\hline & Residential & BDL & BDL & BDL & $\mathrm{BDL}$ & \\
\hline
\end{tabular}


J. Chem. Soc. Nigeria, Vol. 46, No.2, pp $0255-0266$ [2021]

Table 4: Pearson Moment Correlation (r) of Groundwater Quality Parameters at Industrial and Residential Areas in Sango Ota

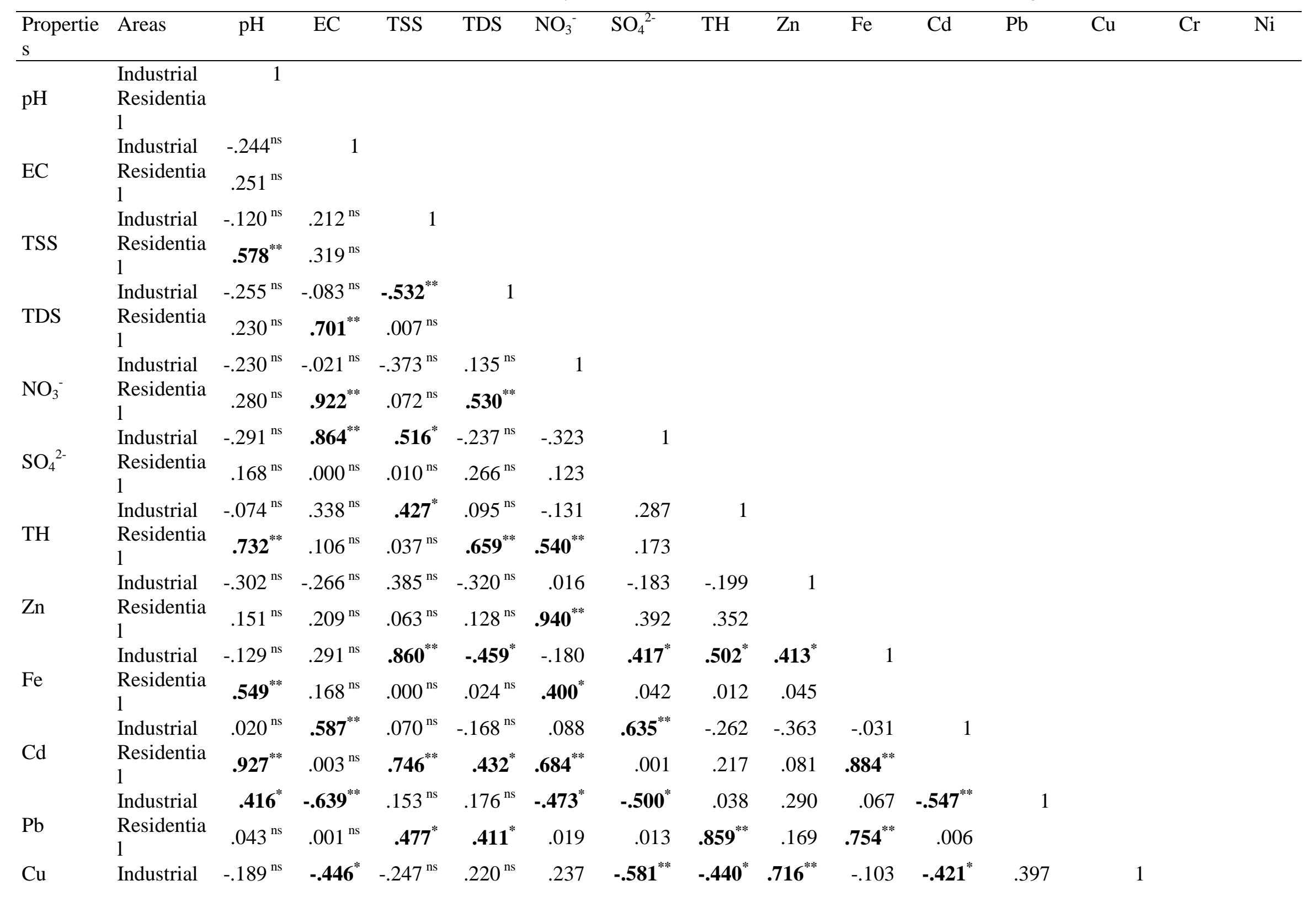


J. Chem. Soc. Nigeria, Vol. 46, No.2, pp 0255 - 0266 [2021]

\begin{tabular}{|c|c|c|c|c|c|c|c|c|c|c|c|c|c|c|}
\hline & $\begin{array}{l}\text { Residentia } \\
1\end{array}$ & $.378^{\mathrm{ns}}$ & $.029^{\mathrm{ns}}$ & $.244^{\mathrm{ns}}$ & $.301^{\mathrm{ns}}$ & .266 & .003 & .032 & .000 & $.633^{* *}$ & .040 & .055 & & \\
\hline \multirow[b]{2}{*}{$\mathrm{Cr}$} & Industrial & $-.668^{* *}$ & $-.460 *$ & $-.251^{\mathrm{ns}}$ & $.417^{*}$ & .281 & -.393 & -.368 & .365 & -.259 & -.314 & .047 & $.561^{* * *}$ & 1 \\
\hline & $\begin{array}{l}\text { Residentia } \\
1\end{array}$ & $.000^{\mathrm{ns}}$ & $.024^{\mathrm{ns}}$ & $.236^{\mathrm{ns}}$ & $.043^{\mathrm{ns}}$ & .184 & .058 & .077 & .079 & .221 & .136 & $.827^{* * *}$ & .004 & \\
\hline $\mathrm{Ni}$ & $\begin{array}{l}\text { Residentia } \\
1\end{array}$ &.$^{\mathrm{c}}$ & c & c & c & c & c & c & c & c & c & c &. & c \\
\hline
\end{tabular}


Electrical conductivity of the groundwater had a strong influence on the $\mathrm{SO}_{4}{ }^{2-}\left(\mathrm{r}=0.864^{* * *}\right)$ and $\mathrm{Cd}\left(\mathrm{r}=0.587^{* *}\right)$ but with a negative relationship on $\mathrm{Pb}\left(\mathrm{r}=-0.639^{* *}\right), \mathrm{Cu}\left(\mathrm{r}=-0.446^{*}\right)$ and $\mathrm{Cr}(\mathrm{r}=$ $\left.-0.460^{*}\right)$ at the industrial area. The negative correlation indicated that abundance of dissolved salt (EC) in the groundwater resulted in a corresponding decrease in concentrations of $\mathrm{Pb}$, $\mathrm{Cu}$ and $\mathrm{Cr}$. At the residential area, increase in $\mathrm{EC}$ of the water also had a significant increase on the TDS $\left(r=0.701^{* *}\right)$ and $\mathrm{NO}_{3}{ }^{-}\left(r=0.922^{* *}\right)$ concentrations. The positive correlation however, showed that EC was controlled by TDS and $\mathrm{NO}_{3}{ }^{-}$, which agrees with the study of [26]. Total suspended solid was negatively correlated with TDS $\left(\mathrm{r}=-0.523^{* *}\right)$ but positively correlated with $\mathrm{SO}_{4}{ }^{2-}, \mathrm{TH}$ and $\mathrm{Fe}$ with coefficients $r$, of $=0.516^{*}, 0.427^{*}$ and $0.860^{* *}$, respectively at the industrial area. This indicated that the amount of solid particles found in the groundwater was a function of its sulphate, hardness property and iron content. Meanwhile, at the residential area, the correlation showed that TSS was a function of $\mathrm{Cd}\left(\mathrm{r}=0.746^{* * *}\right)$ and $\mathrm{Pb}\left(\mathrm{r}=0.477^{*}\right)$. Total dissolved solid in the water sample was negatively correlated with $\mathrm{Fe}\left(\mathrm{r}=-0.459^{*}\right)$ at the industrial area. This indicated that as TDS increases concentration of $\mathrm{Fe}$ in the water decreases and vice versa. However, at the residential the TDS was strongly influenced by $\mathrm{NO}_{3}{ }^{2-}$ and $\mathrm{TH}$ with correlations of $\mathrm{r}=0.530^{* * *}$ and $r=0.659^{* *}$, respectively. The TDS was also positively correlated with $\mathrm{Cd}\left(\mathrm{r}=0.432^{*}\right)$ and $\mathrm{Pb}$ $\left(\mathrm{r}=0.411^{*}\right)$ in the groundwater at the residential area. This implies that these parameters affect the potability of the groundwater samples. Total dissolved solid has been regarded as a measure of water potability [2]. At the industrial area, $\mathrm{NO}_{3}{ }^{2-}$ had an inverse relationship with concentration of $\mathrm{Pb}\left(\mathrm{r}=-0.473^{*}\right)$ in the groundwater. Conversely, $\mathrm{NO}_{3}{ }^{2-}$ in the water was positively influenced by $\mathrm{TH}\left(\mathrm{r}=0.540^{* * *}\right)$, $\mathrm{Zn}\left(\mathrm{r}=0.940^{* *}\right), \mathrm{Fe}\left(\mathrm{r}=0.400^{*}\right)$, and $\mathrm{Cd}(\mathrm{r}=$ $0.684^{* * *}$ ) at the residential area. This could be a reflection of anthropogenic activities at the residential area. According to [2] anthropogenic activities in surrounding environment of groundwater have a strong impact on its nitrate enrichment contamination. The $\mathrm{SO}_{4}{ }^{2-}$ in the groundwater at industrial area showed a significant positive relationship with $\mathrm{Fe}(\mathrm{r}=$ $\left.0.417^{*}\right)$ and $\mathrm{Cd}\left(\mathrm{r}=0.635^{* * *}\right)$ but had a negative relationship with $\mathrm{Pb}\left(\mathrm{r}=-0.500^{*}\right)$ and $\mathrm{Cu}(\mathrm{r}=-$ $\left.0.581^{* *}\right)$. Total hardness was positively correlated with $\mathrm{Fe}\left(\mathrm{r}=0.502^{*}\right)$ and negatively correlated with $\mathrm{Cu}\left(\mathrm{r}=-0.440^{*}\right)$ at industrial area. Meanwhile, at the residential area, the $\mathrm{TH}$ was significantly correlated with $\mathrm{Pb}(\mathrm{r}=$ $\left.0.859^{* *}\right)$. The correlation of $\mathrm{Zn}$ was only significant with $\mathrm{Fe}\left(\mathrm{r}=0.413^{*}\right)$ and $\mathrm{Cu}(\mathrm{r}=$ $\left.0.716^{* * *}\right)$ at industrial area. Concentration of $\mathrm{Fe}$ in the groundwater was however, strongly influenced by $\mathrm{Cd}\left(\mathrm{r}=0.884^{* *}\right), \mathrm{Pb}\left(\mathrm{r}=0.754^{* *}\right)$ and $\mathrm{Cu}\left(\mathrm{r}=0.633^{* *}\right)$ at the residential area. This showed that abundance of $\mathrm{Fe}$ in the groundwater was influenced by these toxic metals hence, people in this area are exposed to potential health risks. Cadmium in the groundwater had an inverse correlation with $\mathrm{Pb}\left(\mathrm{r}=-0.547^{* *}\right)$ and $\mathrm{Cu}\left(\mathrm{r}=-0.421^{*}\right)$ at industrial area. This indicated that the presence of $\mathrm{Cd}$ in the water was not dependent on $\mathrm{Pb}$ and $\mathrm{Cu}$. Meanwhile, $\mathrm{Pb}$ was highly dependent on $\mathrm{Cr}\left(\mathrm{r}=0.827^{* *}\right)$ at residential area while $\mathrm{Cu}$ concentration was a function of $\mathrm{Cr}\left(\mathrm{r}=0.561^{* * *}\right)$ at the industrial area.

\section{CONCLUSIONS}

This study revealed that most of the groundwater samples were slightly acidic. Majority of the water samples were high in, EC, TSS, $\mathrm{SO}_{4}{ }^{2-}$ and $\mathrm{TH}$ at the residential than industrial area. However, high concentrations of TDS and $\mathrm{NO}_{3}{ }^{-}$ were found in $75 \%$ of the groundwater at the industrial over residential area. Among the heavy metals, $\mathrm{Fe}$ and $\mathrm{Pb}$ were above WHO allowable limits for drinking water and hence constitute major health threat in both the industrial and residential areas. Cadmium was also of health concern at location $\mathrm{T} 4$ of the residential area. Therefore, to safe guard people from contacting diseases related to these water contaminants, there is need for government to provide potable water for people in the study area. Government should also focus more on sensitization programme that centered on improved sanitation practices for people who rely on their wells for drinking water. 


\section{ACKNOWLEDGEMENTS}

The authors acknowledge the people that own the wells where water samples were collected

\section{REFERENCES}

[1] R. Vijay, P. Khobragade and P.K. Mohapatra (2011), Assessment of groundwater quality in Puri City, India: an impact of anthropogenic activities. Environ. Monit. Assess., 177:409-418 https://doi.org/10.1007/s10661-0101643-9.

[2] J. Chen, H. Wu, H. Qian and Y. Gao (2017), Assessing Nitrate and Fluoride Contaminants in Drinking Water and Their Health Risk of Rural Residents Living in a Semiarid Region of Northwest China. Expo. Health, 9:183195. https://doi.org/10.1007/s12403016-0231-9.

[3] J.V. Cruz and M.O. Silva (2000), Groundwater salinanization in Pico Island (Azores, Portugal): Origin and mechanisms. Environmental Geology, 39(10):11811189. https://doi.org/10.1007/s002540000109.

[4] D.W. Blowes, C.J. Ptacek, J.L. Jambor and C.G. Weisener (2003), The geochemistry of acid mine drainage. Treatise Geochem., 9:149-204. https://doi.org/10.1016/B0-08-0437516/09137-4.

[5] E.M. De Andrade, H.A. Palacio, I.H. Souza, R.A. de Oliveira Leao and M.J. Guerreiro (2008), Land use effects in groundwater composition of an alluvial aquifer (Trussu River, Brazil) by multivariate techniques. Environmental Research, 106(2):170-177. https://doi.org/10.1016/j.envres.2007.10. 008.

[6] P. Mohapatra, R. Vijay, P. Pujari, S. Sundaray and B. Mohanty (2011), Determination of processes affecting groundwater quality in the coastal aquifer beneath Puri city, India: A multivariate statistical approach. Water Sci Technol., 64: 809-817. https://doi.org/10.2166/wst.2011.605.

[7] C.K. Singh, S. Shashtri and S. Mukherjee (2011), Integrating and thank them for their understanding and cooperation.

multivariate statistical analysis with GIS for geochemical assessment of groundwater quality in Shiwaliks of Punjab, India. Environ. Earth Sci., 62:1387-1405.

[8] L. Belkhiria, L. Mounib and A. Boudoukha (2012), Geochemical evolution of groundwater in an alluvial aquifer: Case of El Eulma aquifer, East Algeria. J. Afr Earth

Sci., $\quad 66-67: 46-55$. https://doi.org/10.1016/j.jafrearsci.2012. 03.001.

[9] R.M. Harrison (2006), Pollution: Causes, Effect and Control. The Royal Society of Chemistry. 3rd edn. pp $340-$ 365.

[10] H. Ayedun, A.M. Gbadebo, O.A. Idowu and T.A. Arowolo (2015), Toxic elements in groundwater of Lagos and Ogun States, Southwest, Nigeria and their human health risk assessment. Environ. Monit. Assess., 187:351. https://doi.org/10.1007/s10661-0154319-7.

[11] H. Qian, P. Li, K.W.F. Howard, C. Yang and X. Zhang (2012), Assessment of groundwater vulnerability in the Yinchuan Plain, Northwest China using OREADIC. Environ. Monit. Assess., 184(6):3613-3628. https://doi.org/10.1007/s10661-0112211-7.

[12] L. Wang, F. Hu, L. Yin, L. Wan and Q. $\mathrm{Yu}$ (2013), Hydrochemical and isotopic study of groundwater in the Yinchuan Plain China. Environ. Earth Sci., 69:2037-2057.

https://doi.org/10.1007/s12665-0122040-1.

[13] J. Chen, H. Wu and H. Qian (2016), Groundwater nitrate contamination and associated health risk for the rural communities in an agricultural area of Ningxia, northwest China. Expo. Health, 8:349-359.

https://doi.org/10.1007/s12403-0160208-8. 
[14] D.G. Barceloux and D. Barceloux (1999), Chromium. Clinical Toxicol., 37(2):173-194.

https://doi.org/10.1081/CLT100102418.

[15] Z.X. Wang, J.Q. Chen, L.Y. Chai, Z.H. Yang, S.H. Huang and Y. Zheng (2011), Environmental impact and site specific human health risks of chromium in the vicinity of a ferroalloy manufactory, China. J. Hazard Mater., 190(1-3): 980985.

https://doi.org/10.1016/j.jhazmat.2011.0 4.039 .

[16] APHA-AWWA-WEF [American Public Health Association-American Water Works Association-Water Environment Federation] (2005), Standard methods for the examination of water and wastewater, 21st edn Washington, DC.

[17] WHO [World Health Organization] (2011) Cleaning and disinfecting wells. The World Health Organization technical notes on drinking-water, sanitation and hygiene in emergencies. 4p.https://www.who.int/water_sanitation _health/publications/2011/tn1_cleaning disinfecting_wells_en.pdf. Accessed 10 July 2019.

[18] M.O. Oladimeji, E. Abata, M.O. Dawodu and A.R. Ipeaiyeda (2009), Effect of refuse dumps on the physicochemical properties of surface water, groundwater and soil in Owo township, Ondo State, Nigeria. Toxicological and Environmental Chemistry, 91(5):979987.

https://doi.org/10.1080/0277224080261 4838.

[19] T.A. Arowolo (2005), Seasonal variation of nitrate- $\mathrm{N}$ in surface and groundwater of south western Nigeria: a preliminary survey. Chemistry and Ecology, 21:83-89. https://doi.org/10.1080/0275754041233 1335997.

[20] WHO [World Health Organization] (2017) Guidelines for drinking-water quality: fourth edition incorporating the first addendum. Geneva: Licence: $\mathrm{CC}$ BY-NC-SA 3.0 IGO.
[21] J. Albretsen (2006), The toxicity of iron, an essential element. Veterinary medicine, 82-90.

[22] M. Jaishankar, T. Tseten, N. Anbalagan, B.B. Mathew and K.N. Beeregowda (2014),

Toxicity, mechanism and health effects of some heavy metals. Interdiscip. Toxicol., $\quad 7(2): 60-72$. https://doi.org/10.2478/intox-20140009.

[23] A. Bernard (2008), Cadmium and its adverse effects on human health. Indian $J$.

Med. Res., 128(4):557-64.

[24] S. Chakraborty, A.R. Dutta, S. Sural, D. Gupta and S. Sen (2013), Ailing bones and

failing kidneys: a case of chronic cadmium toxicity. Ann. Clin. Biochem., 50(5):492-495.

https://doi.org/10.1177/0004563213481

207.

[25] P.N. Obasi and B.B. Akudinobi (2020), Potential health risk and levels of heavy metals in water resources of lead-zinc mining communities of Abakaliki, southeast Nigeria. Applied Water Science, $\quad 10(184): 1-23$. https://doi.org/10.1007/s13201-02001233-z.

[26] N.U. Kura, M.F. Ramli, W.N.A. Sulaiman, S. Ibrahim, A.Z. Aris and A. Mustapha (2013), Evaluation of Factors Influencing the Groundwater Chemistry in a Small Tropical Island of Malaysia. International Journal of Environmental Research and Public Health, 10:18611881.

https://doi.org/10.3390/ijerph10051861. 